\title{
CAPACITY BUILDING OF WOMEN LEADERS VIA MANAGEMENT PROGRAMS
}

\author{
Dzintra Ilisko \\ Daugavpils University, Latvia \\ Karīna Juhneviča \\ Daugavpils University, Latvia \\ Jelena Badjanova \\ Daugavpils University, Latvia
}

\begin{abstract}
Despite of women advancement in politics, business, and other spheres of life, women are largely absent from senior position and are marginalized in terms of power and resources. In Latvia women set up and lead vibrant and successful governmental and private organizations. The purpose of the article is to explore cultural roots of gendered inequality in leadership and economic power positions by the literature review and as reviled in interviews. Interview data reveal the obstacles women need to overcome in their career advancement and their stories of success. Methodology: The study presents a qualitative study on women's leadership as defined in legislation and recent research and is supported by the qualitative inquiry of life stories of seven women engaged in the education's management programs. These women undertake leadership positions in their organizations. Conclusions: To conclude, the goal of equal participation for both male and female players in all significant spheres of life as declared in the international legislation and the United Nations, declarations will strengthen democracy and will promote its proper functioning. The authors assert that higher education through management study programs can also build women's capacity for leadership by assertiveness training and encouraging independent and critical thinkers.
\end{abstract}

Keywords: capacity building, equal participation, management programs, women's leadership.

\section{Introduction}

Majority of contexts, like politics, business, and economy remain male dominated. Women still continue to be underrepresented in many fields, particularly in top management positions. In politics historically men believed to be much better leaders. Lots of research point to barriers that prevent women from attaining leadership positions. Gender stereotypes make managers to view women as less capable or competent to lead an office (Glass \& Cook, 2016; 
Klenke, 2011). As O'Brien and Wegren (2015) assert, inequality between genders are need to be examined by a system approach by considering an interplay of a complex myriad of economic, political, culture and social factors, including socially constructed attitudes about what is men's and women's work. Inglehart and Norris (2003) have observed that cultural norms, values and beliefs also shape gender equality.

Increased processes of globalization and developed new markets brought on a surface may women leaders-entrepreneurs. Current reality of leadership is based on hierarchal bureaucratic structures. The traditional theories on leadership assert that leaders need to be assertive, forceful, authoritative. Recent theories point to such leadership qualities which are more characteristic to females, such as cooperation and collaboration.

\section{Legislation on gender equality}

Discrimination against women takes many forms and can be found in practice. UN (2015) position paper offers indicators how SDG 5 (Sustainable Development Goal 5) should be implemented in practice. The main target as reflected in the document is to ensure full participation and equal opportunities for leadership at all levels for both males and females.

Gender equality has been recognized as the bases for building a sustainable community in major local and international documents (UNESCO, 2002; GAP, 2015; UN, 2015). Gender equality has also been reflected as one of the 17 sustainable development goals as a foundation for a peaceful, prosperous and sustainable world and by putting an imperative to fight for equal access to education and representation in political and economic decision-making processes of both men and women that will benefit societies and humanity at large (EC, 2011). The major document of EU "Strategic Engagement for Gender Equality (2016 - 2019)" (2016) also focuses on the major strategic areas as equality for both sexes in decision making processes, economic independence, dignity and integrity of both sexes. The emphases on promoting women in leadership positions and decision making processes was also emphasized in the GAP (2015) (Global Action Pan). The document points to positive changes that are taking place in the society, namely, the proportion of female heads of institutions increased in 15 of the 20 EU countries in 2014 as compared with the date of year 2014 .

\section{Research methods, procedure and participants}

Research reveals the causes of women's underrepresentation in leadership positions, by focusing on a complex set of factors in maintaining gender 
inequality. While understanding the causes on the unemployment of women, such aspects of sustainability as politics, economy, and culture should be taken into account. Societal factor plays a significant role in determining women's position in the political ladder. Societal issues in the particular society, such as gender equality, access to higher education, and opportunities for women to engage in activities requiring to undertake initiative can contribute or lag behind women's participation in leadership. Women who are overburdened with health issues and survival needs will unlikely engage in governance. Educated women with work experience will likely engage in leadership. Economic factors, such as high level of economic development, economic freedoms, investments in private sectors also can be considered among the significant factors influencing women's leadership participation (World Bank, 2007). Political factors, such as pluralism, freedom to exercise agency, and democratic governance, individual rights and freedoms to exercise agency are also among not the least significant factors influencing women's participation.

For the purpose of the interview the following questions were asked as one hour long interviews with women engaged in different levels of leadership.

Table 1 Interview guide: major topics and questions (adopted from (Folta, Segun, Ackerman, \& Nelson, 2012, p. 4)

\begin{tabular}{|c|c|}
\hline Topic & Question \\
\hline Career path & Can you tell about your career path what led you to where you are \\
\hline \multirow[t]{2}{*}{ Leadership } & $\begin{array}{l}\text { When do you hear the word "leadership," what idea comes to your } \\
\text { mind? Describe the characteristics of a good leaders. Which of the } \\
\text { characteristics do you believe you have? }\end{array}$ \\
\hline & What did you do to promote your leadership skills? \\
\hline \multirow[t]{2}{*}{ Motivation } & What motivated you to work you are doing? \\
\hline & What keeps you motivated? \\
\hline \multirow{2}{*}{$\begin{array}{l}\text { Factors, defining } \\
\text { success }\end{array}$} & Describe please, what made you to be successful? \\
\hline & Describe the obstacles you are facing at your work? \\
\hline
\end{tabular}

The study also explores cultural roots of gendered inequality in leadership and economic power position as a result of the literature review and conducted interviews with women. The participants of the study were seven women currently involved in Master's and Doctor's program of a community management, currently occupying leadership positions in the community and private organizations. All of them have joined the research on a voluntarily bases. 
Dzintra Ilisko, Karīna Juhneviča, Jelena Badjanova. Capacity Building of Women Leaders via Management Programs

Table 2 The profile of the respondents

\begin{tabular}{|l|l|}
\hline White & 7 \\
\hline Latvian & 3 \\
\hline Russian & 4 \\
\hline Age in years at interview & Range 32-60, Mean 49.8 \\
\hline Master's level programs & 4 \\
\hline Doctoral level programs & 3 \\
\hline Role in organization & Management position \\
\hline
\end{tabular}

\section{Limitations of the study}

Due its qualitative character the study does not lead to a formulation of generalizations but point to the tendencies based on literature review and explore cultural roots of gendered inequality in leadership and economic power positions in Latvia by life interviews.

Prior to conducting interviews, a quick survey was carried out to explore the reasons preventing leadership. Participants of the survey were 34 males and 86 female university graduate students.

Table 3 Analysis of causes preventing women from leadership $(\mathrm{N}=120)$

\begin{tabular}{|l|l|}
\hline Question & "Yes" Response rate \\
\hline Why women do not choose leadership positions? & \\
\hline Lack of training & $73 \%$ \\
\hline Women do not choose leadership positions & $82 \%$ \\
\hline Men are better leaders & $92 \%$ \\
\hline Women cannot combine family duties with leadership & $96 \%$ \\
\hline Women believed to be worse leaders than men & $87 \%$ \\
\hline What would encourage women to undertake leadership? & \\
\hline Family & $80 \%$ \\
\hline Mentoring & $74 \%$ \\
\hline Inborn abilities & $93 \%$ \\
\hline
\end{tabular}

Majority of students support women in leadership positions but as a main obstacle they see unequal distribution of time for both genders to carry domestic duties. They also believe that if women have inborn abilities to lead they may do so. Still, having a choice to decide who will carry a leadership position they see males are better suited for the leadership position.

\section{Women's life stories revealed}

The analyses of career trajectories and subjective life experiences of six women provides a more nuanced understanding of obstacles, barriers and opportunities women experienced in their life journeys. All interviewed women had an experience of work in a business, having their own business or work in 
different leadership positions. There are certain categories that can be traced in their stories in the business world.

All women pointed to societal stereotypes that were fostered by their families and the society. These gender stereotypes in some way influenced their beliefs, behavior and self-concept. Many women internalized those stereotypes. The interviews with women allows to conclude that new cultural norms, values and beliefs caused by open market economy and globalization tendencies also shape the transition to gender equality. Women feel more liberated, open to initiative taking and leadership. As one of the respondents remarked: "Open marked economy offers us numerous opportunities and our duty is to accept those challenges. This is up to us to be victim of builders of lives and destinies":

Motivating factors

Among the motivating factors were 'significant other' of a mentor in women's' lives who challenged and encouraged women for undertaking leadership in their communities and their lives. All women could point to the existence of a mentor or a leader in their life who become a symbol of inspiration for their work and life. One of the respondents told the story of the leader who inspired her: "There are so many wise and strategic leaders in my life who serve as a source of inspiration in my life. I cannot copy these people but I get inspired by the way they lead people and by their constructive vision and strategy, the way they inspire people." They pointed out that the mentors were those who helped them to realize their fullest potential in their lives and in the workplace.

Some women mentioned seminars and books as a source of their inspiration. All of them have recognized the value of their studies that allowed to get approval to what and how they were leading their companies and offices and provided challenge for further transformative actions in their personal development and at work. Some of them have mentioned their families as their support factors: "In the economic situation when my husband has lost his job, he fully supports my business plans and challenges?"

Among the factors defying success of their careers women have mentioned: family support, mentoring and challenging learning experience. Two women emphasized new changes that she has to overcome as a driving forces in overcoming obstacles and "celebrating small victories"

\section{Leadership characteristics}

Among the most often mentioned characteristics of a good leader women mentioned a strong vision, charisma, and ability to motivate members of a team: "The best lesson I have learned was by observing powerful leaders in action and their ability to delegate duties, to trust in abilities of team members as well as charisma to motivate people. Of course, I cannot copy these qualities in my work but I can try my best to inspire my team since work in the private business 
company requires involvement of a motivated team to reach the best results possible."

Among the other qualities that were mentioned were patience, communication skills, and ability to create a shared meaning with others as important for the leader.

The qualities of a leader as mentioned by women point to a transformative type of leaders desired by the respondents, the leader who has a vision and a commutative skill to inspire the team and ability to deal with complex and wicked issues, as well to work towards a desired vision. The theme of an inspirational and transformative leader was among the mostly pronounced themes during the interviews.

\section{Causes of underrepresentation of women in leadership positions}

Among the more often mentioned causes by women were double workload and uneven distribution of household chores: "As a woman I am supposed to have a full workload at work, to carry out extra duties at work and having a full responsibility of the domestic duties."

The other more frequently mentioned cause by women were deeply seated cultural bias on biological and psychological profile that make men better leaders and a deeply seated attitude 'think manager - thin male.' Some interviewed women have mentioned that their advancement in their career and time spent in education become a source of conflict and even caused a divorce in their lives since it was not acceptable for their partners such a career and salary gap between both partners. Due to deeply seated cultural stereotypes this seems unacceptable for their male counterparts to accept the career advancement of their wives.

Since males are believed to be a more productive leader, they are paid for the same work much more than for the women. Unfortunately, females monthly average gross wages are lower than males. Still, there is higher unemployment rate among women. This is hard for women to get a job at the age of 45-55. The majority of women choose education as a sphere of their work that is less paid compared to other spheres of work. Women employment is primarily in low pad occupations, such as teaching, nursing, and culture management. As all women pointed out, although the employment level is equal for men and women, men are more likely to be employers.

\section{Conclusions}

Leadership has been a social construct based on expectations of community rather than based on qualities of individual leaders. Community perceives leaders as prototypically male. As a result, women are less likely will be considered for leadership positions because such roles do not fit or the ideal 
model of aggressive an assertive leadership, thus devaluing women's experience. Therefore, women's work and achievements are left unacknowledged or provoke negative reactions.

In overall, women continue to enter traditional women's fields of work, such as teaching, social work, and nursing. The challenge is to situate inequality in a system perspective, economically, culturally, and politically. This is not enough to increase a number of women in leadership positions, one needs to reevaluate the processes and structures that are male based and to explore the ways to change it.

The growth of a global knowledge societies created great opportunities for women and at the same time poses great challenges. In Latvia, the representation of women in the previously dominated field by males of business has increased along with women's occupational representations in managerial positions. Numerous efforts have been made by NGO's to challenge the discriminatory policies and practices of educational establishments. However, the issue of gender equality is not solved yet. Therefore, education has its significant role to play in fostering female participation in leadership.

Educational programs can play a vital role in emphasizing women's agency and empowering women to undertake leadership positions in the community, by helping them to become aware of their capacities and abilities to enter nontraditional fields such as engineering, law and businesses, as well to become active agents in reform processes in education and the society at large, by taking an active role in policy making processes in the country.

Women need to be encouraged to undertake agency by understanding that agency involves recognition of the power of discourse, 'immersion in and indebtedness in that discourse, and a fascination of the play of meaning through which new life-firms may be generated: life forms capable of disrupting old meaning and desires (In Arnot et al., 2006, p. 82).

\section{References}

Arnot, M., Macan, A., \& Ghail, M. (2006). Gender and Education. Routledge: London and New York.

EC (2011). Strategy for Equality Between Women and Men. EC: Brussels.

EC (2015). European Commission Database on Women and Men in Decision-Making. (EU27, plus HR, MK, TR, RS, IS and NO).

Folta, C., Seguin, R. A., Ackerman, J., \& Nelson, M. E. (2012). A qualitative study of leadership characteristics among women who catalyze positive community change. BMC Public Health, 12, 2-12

GAP (2015). Global Action Programme for ESD. Downloaded from: https://en.unesco.org/gap

Glass, C., \& Cook, A. (2016). Leading at the top: Understanding women's challenges above the glass ceiling. The Leadership Quarterly, 27, 51-63. 
Dzintra Ilisko, Karīna Juhneviča, Jelena Badjanova. Capacity Building of Women Leaders via Management Programs

Inglehart, R., \& Norris, P. (2003). Rising tide: Gender equality and cultural change around the world. Cambridge: Cambridge University Press.

Klenke, K. (2011). Women in leadership: Contextual dynamics and boundaries. UK: Emerald Publishing group.

O'Brien, D. J., \& Wegren, S. K. (2015). The Underrepresentation of women in leadership positions in Rural Russia. Rural Sociology, 80 (1), 86-107.

UNESCO (2002). Universal Declaration of Cultural Diversity. Downloaded from: http://unesdoc.unesco.org/images/0012/001271/127162e.pdf

United Nations (UN) (2015). The Sustainable Developmental Goals. Downloaded from: http://www.unmillenniumproject.org/goals/

World Bank (2007). The World Bank Annual Report. Retrieved from: http://siteresources.worldbank.org/EXTANNREP2K7/Resources/English.pdf 